\section{Effects of Low-dose Electron Beam Irradiation on Respiration, Microbiology, Color, and Texture of Fresh-cut Cantaloupe}

\author{
B.B. Boynton ${ }^{2}$, B.A. Welt ${ }^{1}$, C.A. Sims ${ }^{2}$, J.K. Brecht ${ }^{3}$, \\ M.O. Balaban ${ }^{2}$, and M.R. Marshall ${ }^{2}$
}

ADDITIONAL INDEX WORDs. irradiation, MAP, respiration, packaging, cantaloupe, melon

\begin{abstract}
Summary. Cantaloupes (Cucumis melo) in three separate trials were cut into 1 -inch cubes and irradiated at $0,0.25,0.5,0.75,1.0,1.25$, or $1.5 \mathrm{kGy} ; 0,0.1$, $0.2,0.3,0.4,0.5$, or $0.7 \mathrm{kGy}$; and $0,0.3,0.6$, or $0.9 \mathrm{kGy}$, respectively. They were then stored in air at $3{ }^{\circ} \mathrm{C}$ for up to 20 days, and respiration rate, measured as carbon dioxide $\left(\mathrm{CO}_{2}\right)$ production, microbiological counts [total plate count (TPC) and yeast and molds], texture, and color were measured during storage. Respiration rates were initially higher in irradiated cantaloupe. After 8 days, respiration was similar between irradiated and control fruit. Irradiation moderated increases in respiration in a dose-dependent manner. Highest irradiation doses resulted in initial TPC reductions of $1.5 \mathrm{log}$ compared to the non-irradiated controls, and also prevented the 2.5 to $3 \log$ TPC increases seen in controls after 10 to 11 days of storage. Texture differed on day 1 , when controls were most firm, but irradiation maintained greater firmness than controls after day 7 . Irradiation of fresh-cut cantaloupe has potential for shelf life extension and for integration with modified atmosphere packaging systems.
\end{abstract}

$\mathrm{F}$ ood irradiation generally refers to the use of gamma rays from radionuclides, such as cobalt- 60 or cesium-137, or high-energy electrons and/or Bremsstrahlung radiation (commonly referred to as " $\mathrm{x}$-rays") produced by machine sources to treat foods. Two major benefits of irradiation are that a product can be treated in its final package as a terminal treatment (Farkas, 1998), and the temperature of the product is not affected. In a study by Minea et al. (1996), whole strawberries (Fragaria xananassa), cherries (Prunus cerasus, P. avium), apricots (Prunus armeniaca), and apples (Malus $\times$ domestica) were irradiated with an electron accelerator at doses of 0.1-3 kGy at dose rates from 0.1 to $1.5 \mathrm{kGy} \cdot \mathrm{min}^{-1}$. Results showed effective microbial destruction and a great influence on decrease in enzymatic activities. Shelf life extension of

\footnotetext{
University of Florida/IFAS, Gainesville, FL 32611.

${ }^{1}$ Corresponding author; Agricultural and Biological Engineering Department; e-mail: bwelt@ufl.edu; phone: 352.392.1864, ext. 111

${ }^{2}$ Department of Food Science and Human Nutrition.

${ }^{3}$ Horticultural Science Department.

Acknowledgments. This research was supported by the Florida Agricultural Experiment Station, and approved for publication as Journal Series No. R-10779.
}

at least 4-7 d was achieved without significantly affecting sensory properties. In 1986, the U.S. Food and Drug Administration approved the use of ionizing radiation for fruits and vegetables at doses not to exceed 1.0 kGy (U.S. Food and Drug Administration, 2004).

Fresh-cut produce tend to be highly perishable, value added products that have been prepared for immediate and convenient consumption by removal of inedible components such as stems, skin, pits and/or cores. Freshcut produce is often offered for sale in packaging that is specially designed to protect delicate products from physical injury and sometimes to extend shelf life. Fresh-cut produce continues to increase in demand with cantaloupe among the most important in terms of volume produced and value (Guzmán,
1997). Fresh-cut products must not only be aesthetically pleasing, but also comply with food safety requirements. Plant cell injury, senescence, and stress facilitate growth of microorganisms. Potential for survival and growth of microorganisms on fresh-cut products vary in proportion with the amount of injury occurring during the cutting processes (Heard, 1999). Microbial proliferation on fresh-cut cantaloupe is problematic (Ayhan et al., 1998; Bai et al., 2001; Lamikanra and Watson, 2000; O'Connor-Shaw et al., 1994). Human pathogens found on produce include bacteria, viruses, and parasites (Beuchat, 1996). Several outbreaks of food poisoning caused by Salmonella species in recent years have been traced to cantaloupes (Brecht et al., 2004). Irradiation has the potential to eliminate vegetative forms of bacterial pathogens such as Salmonella, as well as parasites, and also to extend fresh-cut product shelf life (Farkas et al., 1997).

To be labeled fresh-cut, fruit tissue must be living and therefore respiring. Respiration involves the consumption of oxygen $\left(\mathrm{O}_{2}\right)$ and production of $\mathrm{CO}_{2}$ and water. Inhibition of respiration and ethylene production, which slows deteriorative changes of senescence, generally extends shelf life (O'ConnorShaw et al., 1996). Therefore, decreasing respiration rate without complete inhibition would benefit produce to be labeled and sold as "fresh-cut."

Consumers expect fresh-cut products to be without defects, of optimum maturity, have a fresh appearance, and have high sensory and nutrient quality (Watada and Qi, 1999). Fresh-cuts are usually more perishable and unstable than original products, due to extreme physical stresses from processes such as peeling, cutting, slicing, shredding, trimming, coring, and removal of protective epidermal cells (Watada et al., 1996). Currently, a total shelf life of about $10 \mathrm{~d}$ is necessary, which includes about $3 \mathrm{~d}$ for marketing and

\begin{tabular}{llll}
\hline $\begin{array}{l}\text { Units } \\
\begin{array}{l}\text { To convert U.S. to SI, } \\
\text { multiply by }\end{array}\end{array}$ & U.S. unit & SI unit & $\begin{array}{l}\text { To convert SI to U.S., } \\
\text { multiply by }\end{array}$ \\
\hline 29.5735 & $\mathrm{fl} \mathrm{oz}$ & $\mathrm{mL}$ & 0.0338 \\
0.3048 & $\mathrm{ft}$ & $\mathrm{m}$ & 3.2808 \\
0.7457 & horsepower & $\mathrm{kW}$ & 1.3410 \\
2.5400 & inch $(\mathrm{es})$ & $\mathrm{cm}$ & 0.3937 \\
25.4000 & inch $(\mathrm{es})$ & $\mathrm{mm}$ & 0.0394 \\
0.4536 & $\mathrm{lb}$ & $\mathrm{kg}$ & 2.2046 \\
28.3495 & $\mathrm{oz}$ & $\mathrm{g}$ & 0.0353 \\
0.9464 & $\mathrm{qt}$ & $\mathrm{L}$ & 1.0567 \\
$\left({ }^{\circ} \mathrm{F}-32\right) \div 1.8$ & ${ }^{\circ} \mathrm{F}$ & ${ }^{\circ} \mathrm{C}$ & $\left(1.8 \times{ }^{\circ} \mathrm{C}\right)+32$
\end{tabular}


retailing (Bai et al., 2001). Extension of shelf life, while maintaining quality, would be advantageous to producers and consumers.

Quality of fresh-cut produce is directly related to wounding associated with processing. Physical wounding and damage also induces additional deleterious physiological changes within produce (Brecht, 1995; Saltveit, 1997). Deterioration symptoms can be perceptible, such as flaccidity from water loss, changes in color, especially browning at the surfaces, and microbial contamination (Brecht, 1995; King and Bolin, 1989; Varaquaux and Wiley, 1994). Wounding also leads to alterations in flavor and aroma volatile production (Moretti et al., 2002).

One of the first responses to wounding is a temporary increase in ethylene production and an enhanced rate of respiration. Increased respiration can lead to excessive losses of nutrients (Brecht, 1995). Ethylene can also stimulate other physiological processes, causing accelerated membrane deterioration, loss of vitamin C and chlorophyll, abscission, toughening, and undesirable flavor changes in many horticultural products (Kader, 1985). Wounding also allows for easier attack and survival of microorganisms.

The purpose of this research was to evaluate potential for irradiation to extend shelflife of fresh-cut cantaloupe. Specifically, effects of irradiation on respiration rates, microbiology, texture, and color of fresh-cut cantaloupe were studied.

\section{Materials and methods}

Fruit sample. Cantaloupes were purchased from a retail market in Gainesville, Fla. (Trial 1 and Trial 2 ) or obtained from a regional supermarket distribution center (Trial 3). Cantaloupes were stored at $25^{\circ} \mathrm{C}$ for $\mathrm{l} \mathrm{d}$ and then placed in a $3{ }^{\circ} \mathrm{C}$ storage room overnight before processing. Cantaloupes were harvested at threequarter to full slip (when a clear separation from the vine occurs with light pressure) and ready to eat.

Processing. Cantaloupes were rinsed in $1.34 \mathrm{~mm}$ chlorinated water and allowed to dry $l \mathrm{~h}$ before cutting. All knives, cutting boards, and bowls were rinsed with $1.34 \mathrm{~mm}$ chlorinated water. Twelve cantaloupes were halved, de-seeded, and then halved again, resulting in four equal parts. Each quarter was sliced on a 1/2-horsepower commercial deli slicer (model 1712E; Hobart Corp., Troy, Ohio) with the blade set at 1 -inch thickness. Slices were then peeled and cut into approximately 1 -inch cubes with a knife. All pieces were placed in an aluminum bowl, which was surrounded with ice. Pieces were thoroughly mixed to assure random sampling.

Fresh-cut cantaloupe cubes $(\sim 300$ g) were placed in 1-qt Ziploc (S.C. Johnson \& Son, Racine, Wis.) freezer bags and sealed after expulsion of air by hand. Bags were placed on ice in a portable cooler and transported to the electron beam irradiation facility, which was 90 mega-amps, 95\% scan (Florida Accelerator Services and Technology, Gainesville, Fla.). Plastic trays were previously frozen with a $1.5-\mathrm{cm}$ layer of ice in the bottom. Four bags were taped to each tray with cantaloupe pieces arranged in a single flat layer in order for all pieces to receive equal dosage. The irradiator's conveyor was set at 3.05 $\mathrm{m} \cdot \mathrm{min}^{-1}$, which provided $0.25 \mathrm{kGy}$ per pass. To achieve predefined dose levels, samples received appropriate numbers of passes, since absorbed dose is cumulative. Samples were removed from ice trays and placed back in the cooler after the desired number of passes. Samples were irradiated at 0 , $0.25,0.5,0.75,1.0,1.25$, and 1.5 kGy for Trial 1. Each pass through the irradiator took about $5 \mathrm{~min}$ and total irradiation time for all trials was approximately $30 \mathrm{~min}$.

Fresh-cut cantaloupe pieces $(\sim 300$ g) from each bag were then placed in 1-quart Ball mason jars (Alltrista Corp., Indianapolis). Jars and lids were sanitized with a laboratory-sanitizing washer and dryer. A 3/8-inch hole was drilled directly in the middle of each jar lid. Parafilm (American National Can, Menasha, Wis.) was wrapped around the top of the jar before applying the lid to assure a gas-tight seal. Jars were stored at $3{ }^{\circ} \mathrm{C}$ for the duration of the experiment. Analyses, as described below, were performed after $1,3,5$, $7,9,12,14,16$, and $18 \mathrm{~d}$.

Trial 2 was carried out exactly as above except the irradiator was set at $0.1 \mathrm{kGy}$ per pass. Samples were irradiated at $0,0.1,0.2,0.3,0.4,0.5$, and $0.7 \mathrm{kGy}$ and evaluated after $1,4,6,8$, $11,13,17$, and $20 \mathrm{~d}$.

Trial 3 was carried out exactly as above except the irradiator was set at $0.3 \mathrm{kGy}$ per pass. Samples were irradiated at $0,0.3,0.6$, and $0.9 \mathrm{kGy}$ and evaluated after $0,2,4,7,10,13$, and $16 \mathrm{~d}$.

Dosimetery. Radiographic dosimeters were placed under bags of fresh-cut cantaloupe, flat on the trays and on top of bags. Gafchromic MD-55 film from International Specialty Products (Wayne, N.J.) was cut into $\mathrm{l} \times \mathrm{l}$ $\mathrm{cm}$ squares, placed in small envelopes, and secured into place. Dosimeter film was allowed to expose for $24 \mathrm{~h}$ and then read on a spectrophotometer at a wavelength of $510 \mathrm{~nm}$. Average absorbed dose per pass was determined by averaging measured dose delivered to dosimeters located above and below sample bags.

GAS ANALYSIs. Headspace analysis was done by sampling gas composition of jars for contents of $\mathrm{O}_{2}$ and $\mathrm{CO}_{2}$ using an $\mathrm{O}_{2}$ and $\mathrm{CO}_{2}$ analyzer (Checkmate 9900; PBI-Dansensor, Ringsted, Denmark). Lids were sealed for $2 \mathrm{~h}$ before sampling by inserting a rubber serum stopper into the hole in each jar lid and were reopened immediately after gas withdrawals. The sampling needle from the gas analyzer was pushed through the rubber stopper and allowed to take several readings and stabilize. Samples were taken in the $3{ }^{\circ} \mathrm{C}$ cold room.

Microbial analysis. Approximately $20 \mathrm{~g}$ of cantaloupe were aseptically removed from the jars and placed in sterile stomacher bags. Samples were diluted $1: 10$ with phosphate buffer and stomached for $30 \mathrm{~s}$. Further 1:10 dilutions were carried out by adding 1 to $9 \mathrm{~mL}$ of phosphate buffer in dilution tubes and vortexing for $30 \mathrm{~s}$. Aerobic Plate Count and Yeast and Mold Plate Count Petrifilm (3M Corp., St Paul, Minn.) were used for all dilutions tested. Petrifilms incubated at $25^{\circ} \mathrm{C}$ for $4 \mathrm{~d}$ until quantified.

Color analysis. Cantaloupe pieces (six per treatment) were aseptically removed from jars and placed on styrofoam plates. In Trial 2, samples were placed in the Color Machine Vision System (Engineering and Cybersolutions, Gainesville, Fla.) consisting of light box and a charge-coupled device (CCD) color camera (DFW-V500; Sony Corp., Japan) connected to a computer, as well as a standard orange reference plate for reference (CIELAB $\mathrm{L}^{*}, \mathrm{a}^{*}$, and $\mathrm{b}^{*}$ values of $24.2,19.7$, and 5.4 , respectively). Images were taken of three sides of the sample and saved on the computer. Images were then analyzed using a Color Expert Color Analysis software system (University of 
Florida, Gainesville). All images were calibrated with the reference plate.

In Trial 3, color of pieces was measured using a hand-held Minolta Chroma Meter CR-2006 (Minolta Camera Co., Osaka, Japan). The instrument was calibrated before each use with a standard white plate D65 Y-94.4, $\mathrm{x}-0.3158$, and $\mathrm{y}-0.3334$. One side of each cube was placed flush against the light source and $\mathrm{L}^{*}, \mathrm{a}^{*}$, and $\mathrm{b}^{*}$ values were measured. All samples were analyzed on two sides. Hue was calculated using Eq. [1] (Billmeyer and Saltzman, 1966).

$\tan ^{-1}(\mathrm{~b} / \mathrm{a}) \times(57.296)$

Texture. Cantaloupe texture was measured using an Instron Universal Testing Instrument (model 4411; Instron Corp., Norwood, Mass.). The same six pieces that were analyzed for color were used for texture measurements. Cantaloupe pieces were placed under a $5.0-\mathrm{mm}$-diameter plunger, establishing zero force contact, and compressed $3 \mathrm{~mm}$ with a $50-\mathrm{kg}$ load cell. The plunger was driven into the piece with a crosshead speed of 30 $\mathrm{mm} \cdot \mathrm{min}^{-1}$. Maximum compression force was measured in kilograms.

Statistical analysis. Data were analyzed using analysis of variance in the SAS system version 8e (SAS Institute, Cary, N.C.). Differences were determined significant if $P<0.05$. Empirical models were determined by best fit using appropriate combinations of variables. Each trial was analyzed separately.

\section{Results and discussion}

RESPIRATION. Respiration rates of fresh-cut cantaloupe of Trial 1 stored at $3{ }^{\circ} \mathrm{C}$ (Fig. 1) were higher in the irradiated treatments than controls through day 3 . Increased respiration in fruits and vegetables, which may continue for days after exposure to irradiation, is one of the most readily discerned direct effects (Romani, 1966). A similar effect of respiratory activity stimulation by irradiation was observed on different apple cultivars (Gunes et al., 2000; Massy et al., 1964). In contrast to the first $3 \mathrm{~d}$ of storage, the respiration rate of the control began to increase after day 7 and was thereafter greater than in all other treatments. The next sample to rise in respiration rate was the lowest irradiation dose, $0.25 \mathrm{kGy}$, followed by the next least irradiated sample of 0.50 $\mathrm{kGy}$. All samples irradiated above 0.50
kGy behaved very similarly throughout the storage.

Respiration rates of the fresh-cut cantaloupe in Trial 2 are shown in Fig. 2. In this trial there was little indication of increased respiration in irradiated samples compared to the controls. A slight decrease in respiration rates occurred in all treatments after day $\mathrm{l}$, which was probably due to recovery from initial cutting for sample preparation. Respiration rates were similar for all samples through day 8 . Statistical differences were observed starting on day 11 , at which point controls were significantly higher than irradiated samples.

Respiration rates observed for Trial 3 (Fig. 3) were similar to those for Trial 2. Headspace analysis was first done at a true time 0 , as the open system was plugged with the rubber stopper immediately upon placing the cantaloupe in jars. Initial wound response is more prevalent with higher respiration rates observed compared to the day 1 of the other trials. Respiration rates of controls increased after day 7 and irradiated samples did not rise until after day 11. Similar effects were seen where higher irradiation doses caused slower increases in respiration rate over time.

Lower respiration rates of irradiated samples is linked to reductions of metabolic activity, with higher doses resulting in greater reductions (Aljouni et al., 1993; Benoit et al., 2000). Increased respiration rate after 7-9 d of storage at $5{ }^{\circ} \mathrm{C}$ of fresh-cut cantaloupe was observed by Aguayo et al. (2004). These data agree with results

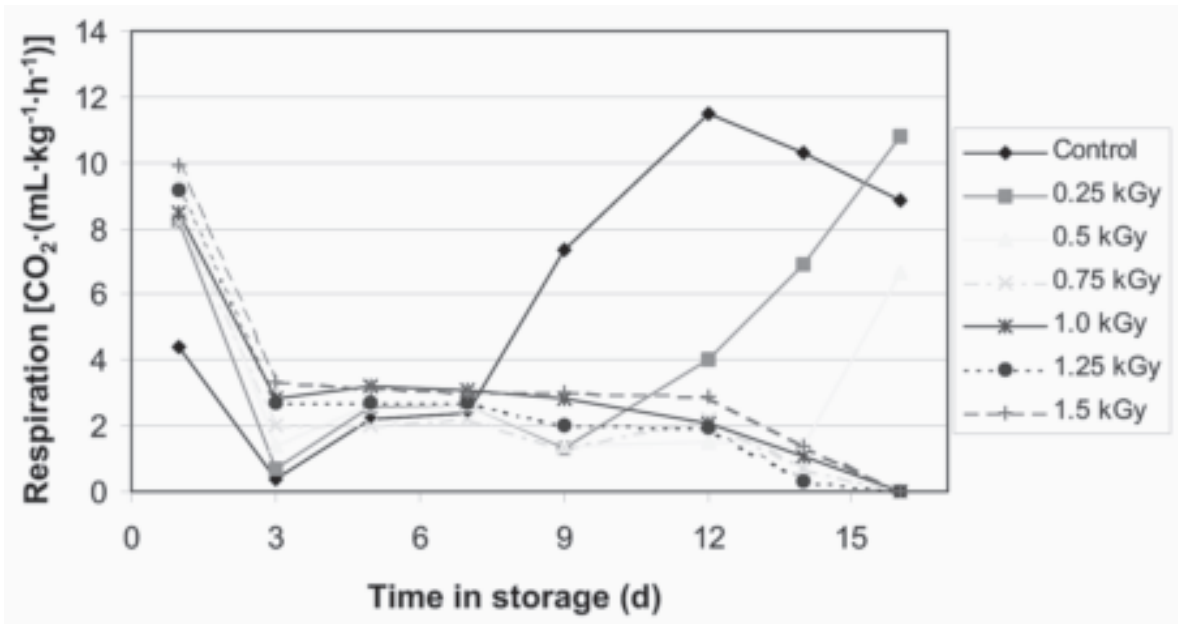

Fig. 1. Respiration rate of irradiated and non-irradiated fresh-cut cantaloupe stored at $3{ }^{\circ} \mathrm{C}\left(37.4^{\circ} \mathrm{F}\right)$ (Trial 1$)$.

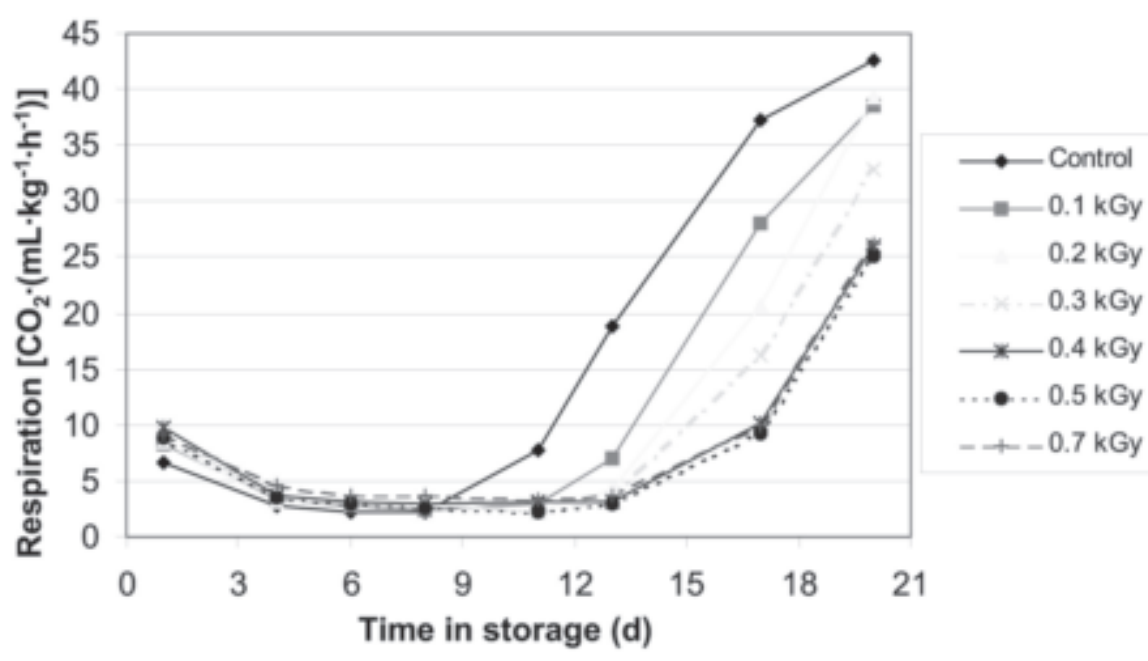

Fig. 2. Respiration rate of irradiated and non-irradiated fresh-cut cantaloupe stored at $3{ }^{\circ} \mathrm{C}\left(37.4^{\circ} \mathrm{F}\right)$ (Trial 2). 
from Bai et al. (2001), Luna-Guzman and Barret (2000), and Madrid and Cantwell (1993). Similar results were found with cut iceberg lettuce (Lactuca sativa), where irradiated samples ( 0.2 and $0.45 \mathrm{kGy}$ ) had higher respiration rates on day $l$ and lower on day 13 (Hagenmaier and Baker, 1997). Possible reasons suggested for maintenance of lower respiration rates in irradiated produce were microbial growth and/or general deterioration of tissue due to senescence. Results reported here indicate that irradiation can reduce or inhibit increases in respiration that normally occur later in storage of fresh-cut cantaloupe.

Comparisons of Figs. 1-3 suggest a practical upper limit for electron beam irradiation of fresh-cut cantaloupe under conditions described. Trial 1 (Fig. 1) involved doses up to $1.5 \mathrm{kGy}$. The figures suggest that doses exceeding $1 \mathrm{kGy}$ may cause irreparable damage to metabolic processes of the freshcut fruit.

Microbiology. Irradiation was responsible for a $1.5 \log$ reduction in total plate count (TPC) at $0.7 \mathrm{kGy}$ on day $\mathrm{l}$ in Trial 2 (Fig. 4). Microbial counts of irradiated samples increased at a lower rate than non-irradiated controls, consistent with the possibility of non-lethal injury to irradiated bacteria as suggested by Welt et al. (2001). TPC for controls and $0.7 \mathrm{kGy}$ samples increased 3.7 and $1.5 \mathrm{log}$, respectively, by day 11 . All samples had TPC levels greater than $10^{8}$ at day 13 except samples treated with $0.4,0.5$, or $0.7 \mathrm{kGy}$. At day 17 , only samples treated with 0.5 or $0.7 \mathrm{kGy}$ had TPC counts below $10^{8}$. Controls were higher than all irradiated samples at days 1, 4, and 13. Irradiation had less affect on the yeast and mold counts (data not shown), with no differences among treatments at any storage times. Yeast and mold counts of all samples increased about $4 \log$ by day 17 .

Yeast and mold counts in Trial 3 were similar to those in Trial 2 with a $4 \log$ increase in all samples by day 13 (data not shown). TPC counts in Trial 3 (Fig. 5) were also similar to Trial 2. The initial $1.5 \log$ reduction of $0.9 \mathrm{kGy}$ samples only increased to $2.5 \log$ rather than $3 \log$ as did the 0.7 $\mathrm{kGy}$ sample in the previous study. At all dates control counts were higher than all irradiation levels.

At day 11 and day 13 , respiration rates of all irradiated samples were

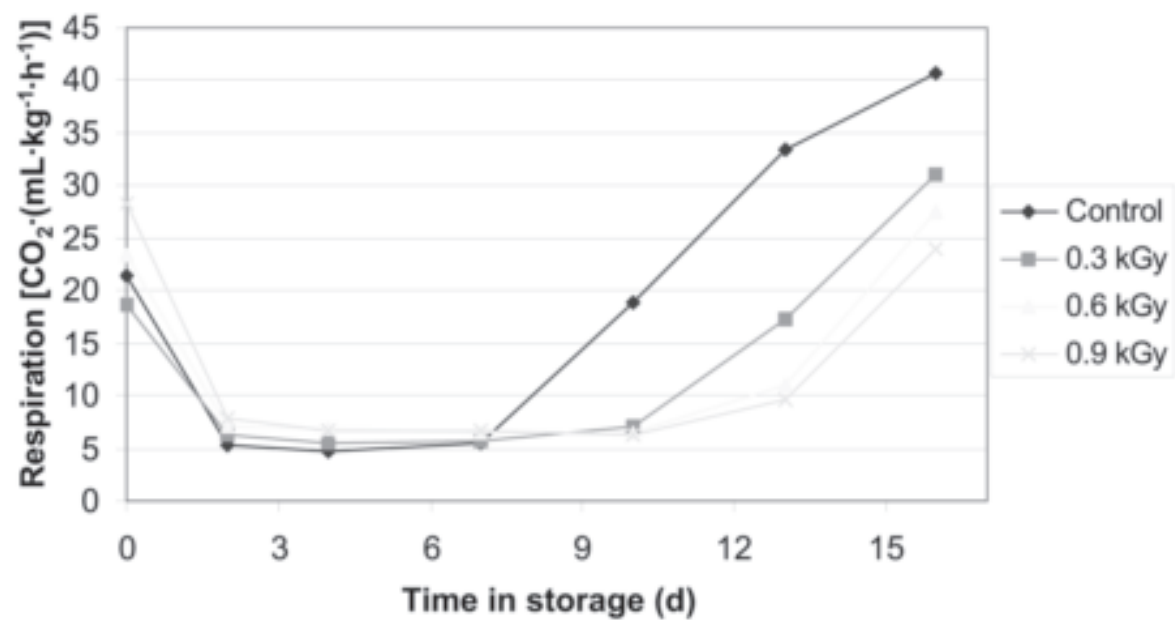

Fig. 3. Respiration rate of irradiated and non-irradiated fresh-cut cantaloupe stored at $3{ }^{\circ} \mathrm{C}\left(37.4^{\circ} \mathrm{F}\right)$ (Trial 3).

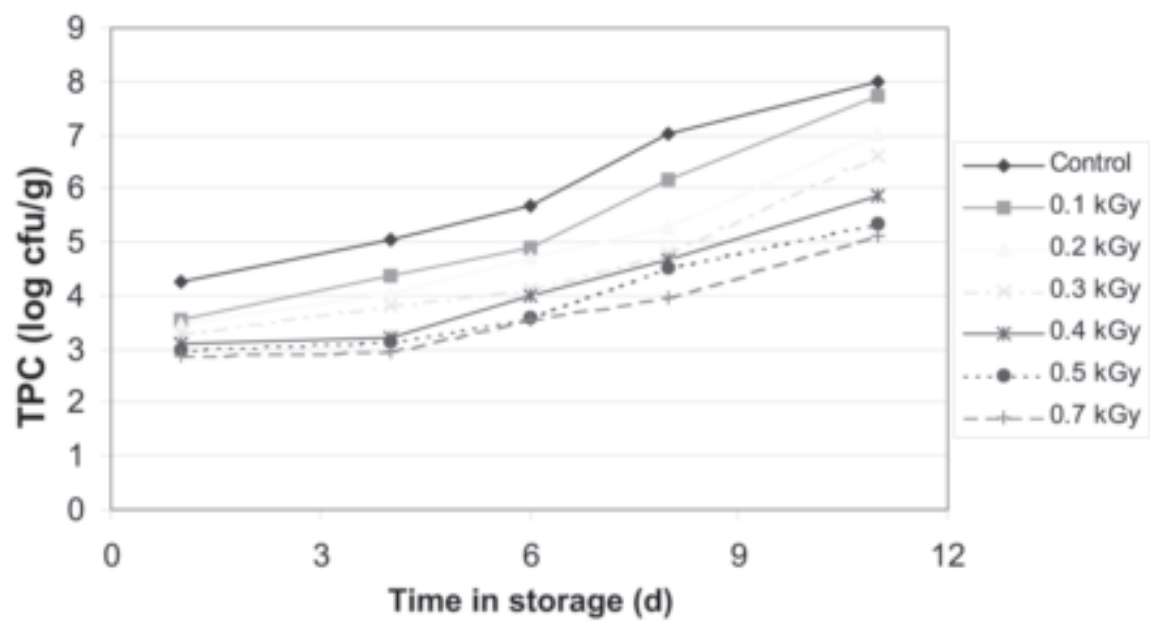

Fig. 4. The total plate count (TPC) of irradiated and non-irradiated fresh-cut cantaloupe stored at $3{ }^{\circ} \mathrm{C}\left(37.4{ }^{\circ} \mathrm{F}\right)($ Trial 2$) ; 1 \mathrm{cfu} / \mathrm{g}=28.35 \mathrm{cfu} / \mathrm{oz}$.

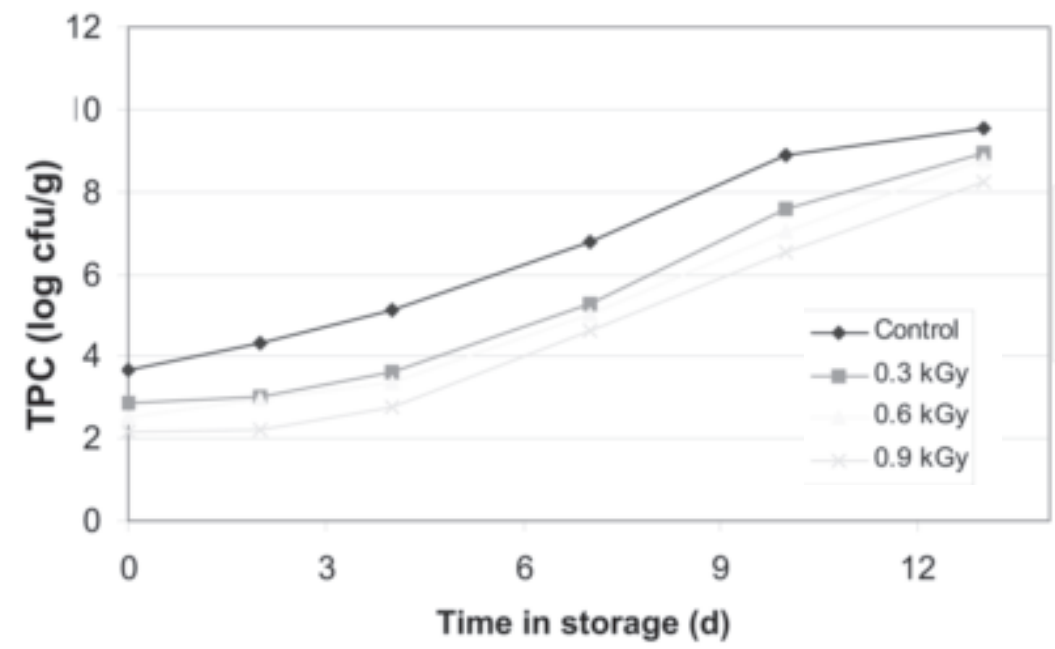

Fig. 5. The total plate count (TPC) of irradiated and non-irradiated fresh-cut cantaloupe stored at $3{ }^{\circ} \mathrm{C}\left(37.4{ }^{\circ} \mathrm{F}\right)($ Trial 3$) ; 1 \mathrm{cfu} / \mathrm{g}=28.35 \mathrm{cfu} / \mathrm{oz}$. 
lower than controls. An analysis of covariance failed to uncover a correlation between microbial populations and observed respiration rates. This suggests that magnitudes of differences in microbial populations did not alter respiration rate results. Additionally, microbial populations on day 13 for the 0.2 and $0.3 \mathrm{kGy}$ treatments appeared to be higher than those of the control on day 11 , yet observed respiration rates for irradiated samples were significantly lower than those observed for controls. Similar results were found in grated carrots irradiated with $2 \mathrm{kGy}$ and stored at $10{ }^{\circ} \mathrm{C}$ in plastic bags (Chervin et al., 1992). In that study, residual concentrations of oxygen were 2 -fold higher in irradiated carrot samples than non-irradiated after $7 \mathrm{~d}$ of storage. Oxygen consumption was determined to be unaffected by microbial contamination ( 5 to $7 \mathrm{log}$ $\mathrm{cfu} / \mathrm{g})$. The correlation coefficient between percent residual oxygen and microbial counts was lower than the significance limit of $r=0.553$ at the 0.05 level, indicating that the two variables are independent (Diem and Seldrup, 1982).

Eq. [2] is an empirical model developed using present results, which can be used to estimate respiration rate of fresh-cut cantaloupe as a function of time and irradiation dose.

$$
\begin{aligned}
\mathrm{RCO}_{2}= & 8.819-1.856 \mathrm{t}+6.053 \mathrm{D} \\
& -0.919 \mathrm{Dt}+0.135 \mathrm{t}^{2}
\end{aligned}
$$

where $t$ is the storage time in days, $\mathrm{D}$ is irradiation dose level in $\mathrm{kGy}$, and $\mathrm{RCO}_{2}$ is the respiration rate in milliliters of $\mathrm{CO}_{2}$ per kilogram per hour.

Variables included in Eq. [2] were determined to be statistically significant $(P<0.0001)$. The model provided an overall coefficient of determination $\mathrm{R}^{2}$ of 0.84 . This empirical model was based solely on data obtained in this study (Trial 2) and is intended to provide a convenient summary of data derived in this work.

Texture. Texture of nonirradiated controls was highest on day 0 , but declined thereafter (Table 1). These data are similar to that for diced tomatoes (Lycopersicon esculentum) (Prakash et al., 2002), apple slices (Gunes et al., 2000), and strawberries (Yu et al., 1996), in which firmness initially

Table 1. Texture of irradiated and non-irradiated fresh-cut cantaloupe stored at $3{ }^{\circ} \mathrm{C}\left(37.4^{\circ} \mathrm{F}\right)$ (Trial 3$)$. Letters a and b compare values in columns and letters $\mathrm{w}-\mathrm{Z}$ compare values in rows with different letters being significantly different $(P$

\begin{tabular}{|c|c|c|c|c|}
\hline & Control & $0.3 \mathrm{kGy}$ & $0.6 \mathrm{kGy}$ & 0.9 kGy \\
\hline & \multicolumn{4}{|c|}{ Texture } \\
\hline & \multicolumn{4}{|c|}{ [maximum force $(\mathrm{kg})]^{\mathrm{z}}$} \\
\hline Day 0 & $0.829 a, w$ & $0.625 a, w x$ & $0.589 a, w$ & $0.607 a, x y$ \\
\hline Day 2 & $0.614 b, x y z$ & $0.735 \mathrm{a}, \mathrm{w}$ & $0.658 \mathrm{a}, \mathrm{w}$ & $0.750 \mathrm{a}, \mathrm{w}$ \\
\hline Day 4 & $0.660 \mathrm{~b}, \mathrm{xy}$ & $0.638 a, w x$ & $0.601 \mathrm{a}, \mathrm{w}$ & $0.701 a, w x$ \\
\hline Day 7 & $0.699 \mathrm{~b}, \mathrm{x}$ & $0.533 a, x$ & $0.679 \mathrm{a}, \mathrm{w}$ & $0.685 a, w x$ \\
\hline Day 10 & 0.553 b,yz & $0.611 a, w x$ & $0.650 a, w$ & $0.667 a, w x$ \\
\hline Day 13 & $0.496 \mathrm{~b}, \mathrm{z}$ & 0.577 a,wx & $0.571 \mathrm{a}, \mathrm{w}$ & 0.508 a.y \\
\hline
\end{tabular}
$<0.05$ ) by analysis of variance.

${ }^{2} 1 \mathrm{~kg}=2.2046 \mathrm{lb}$.

decreased with irradiation. Yu et al. (1996) attributed fruit softening by irradiation to increased water-soluble pectin and decreased oxolate-soluble pectin content.

Canteloupe texture compared by time within treatments is also shown in Table 1. Controls demonstrated greatest declines in firmness. Control cantaloupe cubes softened between day 0 and day 2, while firmness of irradiated cantaloupe cubes did not change during storage. By day 10, irradiated cantaloupe cubes were firmer than the controls. Boyle et al. (1957) reported threshold ranges of irradiation dose on firmness of apples and carrots depending on cultivar, ranging from $\sim 0.04$ to $1.0 \mathrm{kGy}$.

Color. Color of all samples remained stable throughout the storage duration of Trial 2 (Table 2). CIELAB $L^{*}, a^{*}, b^{*}$, and hue values varied more from piece to piece and melon to melon than between treatments. No trends in differences were found between treatments. Absence of browning is likely the result of a lack of polyphenol oxidase enzyme and/or oxidizable phenols in the cantaloupe (Lamikanra and Watson, 2000).

Color results for Trial 3 were similar to Trial 2 except after day 7, when controls were lower in $L^{*}$ (Table 3 ) and in hue on day 13 than treated samples. Loss of color may be attributed to oxidation of $B$-carotene. Hue, chroma and $L^{*}$ values of fresh-cut cantaloupe changed during $25 \mathrm{~d}$ of storage at 4 ${ }^{\circ} \mathrm{C}$ (Lamikanra and Watson, 2000). Irradiation in Trial 3 helped to maintain color after $8 \mathrm{~d}$ of storage.

\section{Conclusions}

Low-dose electron beam irradiation of fresh-cut cantaloupe offers promise as a method of increasing product shelf life. Based on respiration rates, microbiological bloom, and informal sensory evaluations, irradiated samples appeared to maintain preferred quality for 3-5 d longer than non-irradiated controls. Respiration rates of the controls increased after day 8 whereas irradiated samples showed a similar trend only after day 13. Knowledge

Table 2. Color of irradiated and non-irradiated fresh-cut cantaloupe stored at $3{ }^{\circ} \mathrm{C}(37.4$ $\left.{ }^{\circ} \mathrm{F}\right)$ (Trial 2). Values in columns with different letters are significantly different $(P<0.05)$

\begin{tabular}{|c|c|c|c|c|c|c|}
\hline & & & L (Brightness) & & & \\
\hline & day 1 & day 4 & day 6 & day 8 & day 11 & day 13 \\
\hline Control & 70.8 a & 67.9 a & $66.8 \mathrm{ab}$ & $68.0 \mathrm{a}$ & 65.1 a & 65.2 a \\
\hline $0.1 \mathrm{kGy}$ & 71.4 a & 68.7 a & $68.6 \mathrm{ab}$ & 70.3 a & 70.7 a & 69.0 a \\
\hline $0.2 \mathrm{kGy}$ & $67.5 \mathrm{ab}$ & $67.8 \mathrm{a}$ & $62.1 \mathrm{~b}$ & 66.7 a & $68.5 \mathrm{a}$ & 70.6 a \\
\hline $0.3 \mathrm{kGy}$ & $64.1 \mathrm{~b}$ & 71.4 a & $71.6 \mathrm{a}$ & $71.4 \mathrm{a}$ & $72.2 \mathrm{a}$ & 62.8 a \\
\hline $0.4 \mathrm{kGy}$ & 71.4 a & 68.4 a & $67.7 \mathrm{ab}$ & 67.7 a & $68.1 \mathrm{a}$ & $70.8 \mathrm{a}$ \\
\hline $0.5 \mathrm{kGy}$ & $67.0 \mathrm{ab}$ & 67.1 a & $68.3 \mathrm{ab}$ & 66.7 a & $70.8 a$ & 62.3 a \\
\hline $0.7 \mathrm{kGy}$ & $70.2 \mathrm{a}$ & $69.0 \mathrm{a}$ & $67.3 \mathrm{ab}$ & $64.4 \mathrm{a}$ & $67.0 \mathrm{a}$ & $68.3 \mathrm{a}$ \\
\hline & day 1 & day 4 & $\begin{array}{l}\text { Hue } \\
\text { day } 6\end{array}$ & day 8 & day 11 & 13 \\
\hline Control & $66.1 \mathrm{a}$ & $60.0 \mathrm{a}$ & $65.2 \mathrm{ab}$ & $70.6 \mathrm{a}$ & $66.6 \mathrm{a}$ & $61.9 \mathrm{a}$ \\
\hline $0.1 \mathrm{kGy}$ & 62.5 a & 62.3 a & $66.4 \mathrm{ab}$ & 69.6 a & $74.6 \mathrm{a}$ & 69.8 a \\
\hline $0.2 \mathrm{kGy}$ & $67.0 \mathrm{a}$ & $61.7 \mathrm{a}$ & $57.8 \mathrm{~b}$ & $61.5 \mathrm{a}$ & 67.4 a & $72.0 \mathrm{a}$ \\
\hline $0.3 \mathrm{kGy}$ & 58.4 a & 66.2 a & 72.1 a & $71.2 \mathrm{a}$ & 73.9 a & 56.8 a \\
\hline $0.4 \mathrm{kGy}$ & 66.0 a & 61.8 a & $62.5 \mathrm{ab}$ & $65.0 \mathrm{a}$ & 65.2 a & 69.6 a \\
\hline $0.5 \mathrm{kGy}$ & 65.3 a & 60.6 a & $67.0 \mathrm{ab}$ & $63.0 \mathrm{a}$ & $71.4 \mathrm{a}$ & 54.9 a \\
\hline $0.7 \mathrm{kGy}$ & 65.8 a & 62.9 a & $62.1 \mathrm{ab}$ & 55.9 a & $61.3 \mathrm{a}$ & 66.6 a \\
\hline
\end{tabular}
by analysis of variance. 
Table 3. Color of irradiated and non-irradiated fresh-cut cantaloupe stored at $3{ }^{\circ} \mathrm{C}(37.4$ $\left.{ }^{\circ} \mathrm{F}\right)$ (Trial 3). Values in columns with different letters are significantly different $(P<0.05)$.

\begin{tabular}{|c|c|c|c|c|c|c|}
\hline & \multirow[b]{2}{*}{ Day 0} & \multicolumn{3}{|c|}{ L (Brightness) } & \multirow[b]{2}{*}{ Day 10} & \multirow[b]{2}{*}{ Day 13} \\
\hline & & Day 2 & Day 4 & Day 7 & & \\
\hline Control & 63.7 a & 63.7 a & 65.5 a & $57.0 \mathrm{a}$ & $46.6 \mathrm{~b}$ & $42.9 \mathrm{~b}$ \\
\hline $0.3 \mathrm{kGy}$ & 64.0 a & 64.5 a & $58.3 \mathrm{ab}$ & 55.7 a & 61.5 a & 62.4 a \\
\hline $0.6 \mathrm{kGy}$ & 62.7 a & $63.8 \mathrm{a}$ & $63.6 \mathrm{a}$ & 60.8 a & 62.2 a & 53.7 a \\
\hline $0.9 \mathrm{kGy}$ & 62.6 a & $62.3 \mathrm{a}$ & $54.5 \mathrm{~b}$ & 62.6 a & 59.7 a & $54.6 \mathrm{a}$ \\
\hline
\end{tabular}

\begin{tabular}{|c|c|c|c|c|c|c|}
\hline & & & Hue & & & \\
\hline & Day 0 & Day 2 & Day 4 & Day 7 & Day 10 & Day 13 \\
\hline Control & 69.4 a & 71.6 a & 70.7 a & 70.5 a & $73.1 \mathrm{a}$ & $74.5 \mathrm{a}$ \\
\hline $0.3 \mathrm{kGy}$ & 70.5 a & 70.6 a & 70.7 a & 71.7 a & 71.2 a & $71.2 \mathrm{~b}$ \\
\hline $0.6 \mathrm{kGy}$ & $70.4 \mathrm{a}$ & 70.0 a & 70.7 a & 68.7 a & 71.4 a & $71.2 \mathrm{~b}$ \\
\hline 0.9 kGy & 70.0 a & 70.9 a & $71.4 \mathrm{a}$ & 70.9 a & $72.3 \mathrm{a}$ & $70.0 \mathrm{~b}$ \\
\hline
\end{tabular}

Luna-Guzman, I. and D.M. Barret. 2000. Comparison of calcium chloride and calcium lactate effectiveness in maintaining shelf stability and quality of fresh-cut cantaloupes. Postharvest Biol. Technol. 19:61-72.

Madrid, M. and M. Cantwell. 1993. Use of high $\mathrm{CO}_{2}$ atmosphere to maintain quality of intact and fresh-cut melon. Northeast Reg. Agr. Eng. Serv. 6th Intl. Controlled Atmosphere Res. Conf. Proc. 2:736-45.

Minea, R., C. Oproiu, S. Pascanu, C. Matei, and O. Ferdes. 1996. Preliminary research concerning the use of electron accelerators to improve the conservability and to extend the shelf-life of fruits and vegetables. Nuclear Instruments

of effects of irradiation on product respiration rates, as summarized in $\mathrm{Eq}$. [2], should provide a means to develop modified atmosphere packaging that could further enhance the ability of irradiation to extend fresh-cut cantaloupe shelf life.

\section{Literature cited}

Aguayo, E., V.H. Escalona, and F. Artes. 2004. Metabolic behavior and quality changes of whole and fresh processed melon. J. Food Sci. 69:148-155.

Aljouni, S., R.B. Beelman, and D.B. Thompson. 1993. Influence of gamma irradiation on quality characteristics, sugar content, and respiration rate of mushrooms during postharvest storage, p. 103-121. In: Food flavors, ingredients, and composition. Proc. 7th Intl. Flavor Conf., Pythagorion, Samos, Greece. Elsevier, New York.

Ayhan, Z., G.W. Chism, and E.R. Richter. 1998. The shelf life of minimally processed fresh cut melons. J. Food Quality 21:29-40.

Bai, J., R.A. Saftner, A.E. Watada, and Y.S. Lee. 2001. Modified atmosphere maintains quality of fresh-cut cantaloupe (Cucumis melo L.). J. Food Sci. 66(8):1207-1211.

Benoit, M.A., G. D'Aprano, and M. Lacroix. 2000. Effect of gamma irradiation on phenylalanine ammonia-lyase activity, total phenolic content, and respiration of mushrooms (Agaricus bisporus). J. Agr. Food Chem. 48:6312-6316.

Beuchat, L.R. 1996. Pathogenic microorganisms associated with fresh produce. J. Food Protection 59:204-216.

Billmeyer, F.W. and M. Saltzman. 1966. Principles of color technology. Interscience Publ., New York.

Boyle, F.P., Z.I. Kertesz, R.E. Glegg, and M.A. Connor. 1957. Effects of ionizing radiations on plant tissues. II. Softening of different varieties of apples and carrots by gamma rays. Food Res. 2:89-95.

Brecht, J.K. 1995. Physiology of lightly processed fruits and vegetables. HortScience 30:18-22.

Brecht, J.K., M.E. Saltveit, S.T. Talcott, K.R. Schneider, K. Felkey, and J.A. Bartz. 2004.
Fresh-cut vegetables and fruits. Hort. Rev. $30: 185-251$

Chervin, C., C. Triantaphylides, M.F. Libert, R. Siadous, and P. Boisseau. 1992. Reduction of wound-induced respiration and ethylene production in carrot root tissues by gamma irradiation. Postharvest Biol. Technol. 2:7-17.

Diem, K. and J. Seldrup. 1982. Introduction to statistics, p. 63. In: C. Lentner (ed.). Geigy scientific tables, 2. Ciba-Geigy, Basel, Switzerland.

Farkas, J. 1998. Irradiation as a method for decontaminating food. Intl. J. Food Microbiol. 44:189-204.

Farkas, J., T. Saray, C. Mohacsi-Farkas, C. Horti, and E. Andrassy. 1997. Effects of low-dose gamma irradiation on shelflife and microbiological safety of precut/prepared vegetables. Adv. Food Sci. 19:111-119.

Gunes, G., C.B. Watkins, and J.H. Hotchkiss. 2000. Effects of irradiation on respiration and ethylene production of apple slices. J. Sci. Food Agr. 80:1169-1175.

Guzmán, I.L. 1997. Food safety and fresh cut cantaloupe. Perishables Handling Qrtly. 91:13-14.

Hagenmaier, R.D. and R.A. Baker. 1997. Low-dose irradiation of cut iceberg lettuce in modified atmosphere packaging. J. Agr. Food Chem. 45:2864-2868.

Heard, G. 1999. Microbial safety of ready-to-eat salads and minimally processed vegetables and fruits. Food Austral. 51:414-420.

Kader,A.A. 1985. Ethylene-induced senescence and physiological disorders in harvested horticultural crops. HortScience 20:54-57.

King, A. and H. Bolin. 1989. Physiological and microbiological storage stability of minimally processed fruits and vegetables. Food Technol. 43:132-135, 139

Lamikanra O., J.C. Chen, D. Banks, and P.A. Hunter. 2000. Biochemical and microbial changes during the storage of minimally processed cantaloupe. J. Agr. Food Chem. 48(12):5955-61.

Lamikanra, O. and M.A. Watson. 2000. Cantaloupe melon peroxidase: Characterization and effects of additives on activity. Nahrung 44:168-172.
Methods Physics Res. B 113:99-102.

Moretti, C.L., E.A. Baldwin, S.A. Sargent, and D.J. Huber. 2002. Internal bruising alters aroma volatile profiles in tomato fruit tissues. HortScience 37:378-382.

O'Connor-Shaw, R.E., R. Roberts, A.L. Ford, and S.M. Nottingham. 1994. Shelf life of minimally processed honeydew, kiwifruit, papaya, pineapple and cantaloupe. J. Food Sci. 59:1202-1206, 1215 .

O'Connor-Shaw, R.E., R. Roberts, A.L. Ford, and S.M. Nottingham. 1996. Changes in sensory quality of sterile cantaloupe dice stored in controlled atmospheres. J. Food Sci. 61:847-851.

Prakash, A., J. Manley, S. DeCosta, F. Caporaso, and D. Foley. 2002. The effects of gamma irradiation on the microbiological, physical and sensory qualities of diced tomatoes. Radiation Physics Chem. 63:387-390.

Romani, R.J. 1966. Biochemical responses of plant systems to large doses of ionizing radiation. Radiation Bot. 6:87-104.

Saltveit, M. 1997. Physical and physiological changes in minimally processed fruits and vegetables, p. 205-220. In: F.A. Tomas-Barberan and R.J. Robins (eds.). Phytochemistry of fruits and vegetables. Oxford Univ. Press, London.

U.S. Food and Drug Administration. 2004. Code of Federal Regulations 21CFR179.26.

Varaquaux, P. and R. Wiley. 1994. Biological and biochemical changes in minimally processed refrigerated fruits and vegetables, p. 226-268 In: R.C. Wiley (ed.). Minimally processed refrigerated fruits and vegetables. Chapman and Hall, New York.

Watada, A. and L. Qi. 1999. Quality of fresh-cut produce. Postharvest Biol. Technol. 15:201-205.

Watada, A., N. Ko, and D. Minott. 1996. Factors affecting quality for fresh-cut horticultural products. Postharvest Biol. Technol. 9:115-125.

Welt, B.A., A.A. Teixera, M.O. Balaban, G.H. Smerage, D.E. Hintenlang, and B.J. Smittle 2001. Irradiation as a pretreatment to thermal processing. J. Food Sci. 66:844-849.

Yu, L., C.A. Reitmeier, and M.H. Love. 1996. Strawberry texture and pectin content as affected by electron beam irradiation. J. Food Sci. 61:844-846. 